Received March 15, 2020

Revised May 28, 2020

Accepted June 2, 2020

\title{
The Paris Agreement and the Prospects for Socialization into the Climate Norm: Lessons from the U.S. and China
}

\author{
JINHYUN LEE*
}

The Paris Agreement made a breakthrough amid the deadlock in climate negotiations, yet concerns are raised regarding how much impact the new voluntary climate regime can make. This paper investigates the socialization mechanism that the Paris Agreement sets up and explores the prospects of "institutional transformation" for it to make a dent. It examines the factors that can facilitate voluntary climate action by using the cases of the most recalcitrant emitters, the United States and China. It argues that the US and China cases suggest that the socialization from the bottom-up by domestic actors may be one of the critical elements that determine states' position on climate change.

Keywords: Paris Agreement, Global Climate Governance, Institutional Transformation, Socialization, Power and Norms, Climate Politics

* Ph.D.Candidate, Ewha Womans University, Seoul, South Korea; 


\section{INTRODUCTION}

On February 27, 2020, the U.K. court of appeal ruled plans for a third runway at Heathrow airport illegal, which is the first major court ruling in the world referring to the Paris Agreement. The ruling stated that the U.K. government did not adequately take into consideration its commitments to the Paris Agreement (Carrington 2020). Despite decades-long protest against the plan by environmental activists, the U.K. government and the Parliament had pushed the plan. Nonetheless, the court put the country's responsibility to tackle climate change ahead of its economic arguments (Laville 2020).

The U.K. government had been pursuing competing goals. While it decided to press ahead with the Heathrow expansion plan in 2018, it also set a target of net-zero emissions by 2050 in 2019 (Carrington 2020). In the meantime, the U.K. public singled out climate change as the most important issue in the world (Hope not Hate 2019). According to a poll conducted in 2019, 67\% answered that they felt they should limit air travel in order to address climate change (CAST 2019). Moreover, the business's case for economic gains from the airport expansion does not hold water when most international flights are not for business, and only $20 \%$ of the British population take over $65 \%$ of international flights (Carrington 2020). In a sense, therefore, the U.K. government's decision not to appeal against the Heathrow expansion ruling is responding to public demands for climate action.

This illustrates well how domestic contexts can influence a state's position regarding whether to implement international pledges. The turn of events regarding the Heathrow expansion may be caricatured by the shift of the government's position following competing demands from society. The decision to press ahead with the plan in 2018 was made in the midst of economic fear in relation to Brexit, yet the public support for the plan began to wane as public awareness of climate change rose with increasing incidents of floods and extreme weather, as well as with enhanced mass protests worldwide, most notably Global Climate Strike in September 2019. While the change in the position of the U.K. government would not have happened without the court ruling, it was the Paris Agreement that the court based its decision on. On the other hand, the same would not be observed in other countries with similar business interests and public support, if the institutional features such as the independence of the judiciary, differed from the U.K. In other words, despite the skepticism regarding the effectiveness of the Paris Agreement in the absence of an enforcement mechanism, the British example demonstrates the potential of the Paris Agreement for inducing changes, but how other party states will react will vary with their domestic contexts.

The Paris Agreement opened a new phase in global climate governance. It 
sets up a regime that relies on "naming and shaming" to ensure implementation, instead of legal sanctions (Obergassel et al. 2015, 2016). In essence, the Paris Agreement introduces a "pledge and review" system (Keohane and Oppenheimer 2016) under which party states take stock of their collective progress and put forward emission reduction plans every five years (UNFCCC 2015, Article 14.1). Under the Paris Agreement, what is legally binding is the obligations of "pledge and review," not of meeting the pledged targets (Obergassel et al 2015, 248; Keohane and Oppenheimer 2016, 147). In other words, the Paris Agreement establishes "legally binding obligations of conduct, but not obligations of results" (Obergassel et al 2016, 7), which allows for possible gaps between what states pledge and what they implement.

Given the absence of enforcement mechanisms, limiting global warming requires states' voluntary domestic implementation through the internalization of climate norms among domestic actors. Socialization in international relations can take place through interactions among actors. International institutions are said to provide such a venue for interactions. Institutional transformation (Wendt 1992) indicates a change of states' interests through interactions within an international institution. The negotiation processes under the UNFCCC have offered such an opportunity for socialization, and the UNFCCC has played the catalytic function of "injecting a significant momentum into national discussions" (Obergassel et al. $2016,3)$. In the previous discussions of socialization in international relations, nonetheless, the targets of socialization are usually "states and individual policymakers" (Checkel 2005, 804). However, the state-level interactions within the UNFCCC do not necessarily trigger domestic norm-internalization, yet a state's policymakers are influenced by domestic actors and politics as the Heathrow expansion episode shows. This points to the need for a theoretical development for socialization that incorporates domestic actors and domestic contexts.

Without aiming to generalize the findings into other countries, this paper explores the prospects for socialization under the new climate regime within the UNFCCC by examining the U.S. and China cases. The success of the Paris Agreement crucially counts on the U.S. and China, which account for more than $40 \%$ of the global $\mathrm{CO} 2$ emissions. Nonetheless, their commitments are far from reliable. The Obama administration put in great efforts to reach a deal in Paris, yet the Trump administration announced its intention to withdraw from the Paris Agreement. In contrast, China, a champion of the right to develop, changed its position by compromising some of their stances. Currently, China is eager to take a leadership role in climate change (Chiu 2017; Finamore 2018). Despite this contrast in the international arena, the actual domestic progress of emissions reductions shows a different pattern. The U.S. has made a significant emissions reduction, and China has been struggling to do so in the face of economic 
slowdown (IEA 2020). How can the discrepancies between international commitments and domestic implementation be explained? What lessons can be learned from the U.S. and China cases regarding the socialization prospects of the Paris Agreement?

This paper uses existing international theories on international cooperation and compliance and highlights their limitations by using the U.S. and China cases. It argues that the causal factors identified by the state-centric approaches that treat a government's decisions as the stat's decisions lack explanatory power when there exist gaps between international commitments and domestic implementation. This paper identifies alternative factors that facilitate/block norm-internalization. It appears too early to evaluate the progress of the Paris Agreement, but this paper utilizes the fact that domestic actors' preferences and domestic structures - institutional features and state-society relations, ${ }^{-}$do not change quickly. The U.S. and China were not under the obligations of the Kyoto Protocol, therefore, the changes in climate policies have been due to domestic demands, rather than due to the obligations imposed by the international treaty. In this sense, the pre-Paris Agreement societal environment can be used in understanding the domestic contexts. This way this paper attempts an initial assessment based on the past responses of domestic actors in the two countries with regards to climate change.

\section{THE PARADIGM SHIFT IN GLOBAL CLIMATE GOVERNANCE}

International consensus regarding the need to take collective climate action was reached earlier. The global climate discussion started at the 1972 U.N. Conference on Human Environment (UNCHE) held in Stockholm, where the emergence of an environmental movement was catalyzed. It was at the 1992 U.N. Conference on Environment and Development (UNCED) in Rio, where a universally accepted climate norm was created by three primary outcomes of the Rio conference. Main contents of the initial international climate norm that this paper focuses on include the "polluter should bear the cost of pollution" (Rio Principle 16), the "Common but Differentiated Responsibilities" (CBDR) (Rio Principle 7; UNFCCC 1992, Article 3.1), the financial assistance from developed countries to developing countries and the principle of regular reporting on current and predicted national Greenhouse gas (GHG) emissions (UNFCCC 1992, Article 4). These principles lie at the center of the contentions that made the U.S. and China block the progress at the international climate negotiations.

The paradigm shifts that the Paris Agreement has brought are related to how to implement international climate principles in practice. This paper identifies three relevant changes. Firstly, the Paris Agreement obliges all parties 
to "prepare, communicate and maintain successive nationally determined contributions that it intends to achieve" (UNFCCC 2015, Article 4.2). It also specifies that developed and developing countries alike "are encouraged to move over time towards economy-wide emission reduction or limitation targets in the light of different national circumstances" (UNFCCC 2015, Article 4.4). The Kyoto Protocol (UNFCCC 1997) implemented the international UNFCCC norms as legally binding targets and timetables. Only Annex I countries (advanced countries) are obliged to abide by the targets and timetables, and non-Annex I countries were exempt. Secondly, under the Paris Agreement, each party voluntarily commits to the domestically acceptable levels, and to "communicate a nationally determined contribution every five years" (UNFCCC 2015, Article 4.9). Nonetheless, they do not have to keep their pledge, as long as they "shall pursue domestic mitigation measures, to achieve the objectives of such contributions" (UNFCCC 2015, Article 4.2). Thirdly, each party to the Paris Agreement is to "periodically take stock of the implementation of this Agreement to assess the collective progress towards achieving the purpose of this Agreement and its long-term goals" (UNFCCC 2015, Article 14.1). The first formal review, referred to in the agreement as the "global stocktake" (UNFCCC 2015, Article 14.1), is scheduled for 2023, with subsequent review reports submitted every five years thereafter (UNFCCC 2015, Article 14.2).

This "discretion and vagueness" (Keohane and Oppenheimer 2016, 146147) facilitated the negotiation process significantly by lowering the burden of obligations. Each party of the Paris Agreement needs to pledge, but all they have to do is to "review" every five years and demonstrate their efforts to mitigate and meet their pledges (Falkner 2016, 1108). The contents of the Paris Agreement reflect the decades of contentions among states regarding how to implement the internationally agreed climate principles and are the result of the compromise to get the top two emitters on board (Obergassel et al. 2015, 245-248).

The Paris Agreement follows the principle of social construction in the sense that the detailed rules are still under construction, and socialization through "naming and shaming" replaces sanctions and penalties. It is a "process-oriented framework agreement" (Christoff 2016, 776) that is "facilitative, effecting processes for participation rather than creating legal obligations" (Christoff 2016, 775) with many aspects of details - rules, modalities and guidelines for the new market mechanisms, the enhanced transparency framework and the five-year global stock-take and updating process - left to be fleshed out in the later negotiations (Bodansky 2016, 291). The effectiveness of socialization mechanisms depends on how each party state responds. 


\section{INSTITUTIONAL TRANSFORMATION: AN ANALYTICAL FRAMEWORK}

This paper argues that state-level discussion of socialization is not very informative (Johnston 2001, 493) because treating states as unitary actors provide only limited explanations regarding the incentives of states' norm-compliance. It contends that domestic contexts that influence the government's decision need to be examined to understand a state's behavior. This section presents an analytical framework that will be used to put forward this argument. Firstly, testable implications on institutional transformation from existing international relations theories are presented. Then how this paper discusses the domestic contexts to assess the prospects for socialization, or institutional transformation.

Socialization in international relations delivers various meanings (Johnston 2008, 2-6), but it refers to "a process of inducting actors into the norms and rules of a given community" (Checkel 2005, 804) in this paper. Through the repeated interactions at the negotiations, peer pressures operate to socialize and encourage states to behave in specific ways. That is, "states are socialized to want certain things by the international society in which they and the people in them live" (Finnemore 1996, 2).

This paper focuses on the institutional transformation, distinguished from compliance and socialization, to discuss the prospects of the voluntary Paris climate regime. The "institutional transformation" (Wendt 1992, 410-411) indicates a change in preference of a state following the norms promoted by an institution (p. 394). Compliance refers to a change of behavior in line with norms. Socialization refers to the whole process, from a change of behavior (norm-compliance) to a change of values, identity, or preferences (or norm-internalization or the institutional transformation). The prospect of the Paris Agreement will be influenced by major emitters' "sustained compliance" (Checkel 2005, 804), or "durable conformity" (Johnston 2008, 23). In the absence of an enforcement mechanism, therefore, the institutional transformation is required so that states change their policy priority voluntarily despite the costs it entails.

Identification of institutional transformation, or identification of a change in preferences of states, however, poses two challenges. The first difficulty is that preference is not observable: one can only infer it from the observable choices given observable constraints (Hooghe 2005, 865). As Johnston (2001) argues, "what often may appear to be a change in preferences may, instead, be a change in strategies" (p. 491). The second issue is the fact that states are not unitary actors. Various actors with different preferences constitute a state, and the behavior of the state in the international arena is the outcome obtained as a result of domestic politics. Therefore, this study utilizes existing theories to map observable factors into the unobservable institutional transformation, by which it 
highlights the limitation of the discussion of socialization at the state-level. In the rest of the section, four different theories on the role of international institutions and on why states comply will be drawn on to state propositions regarding the institutional transformation.

Firstly, although there being variations within them (Snidal 1985, 585590), scholars advocating hegemonic stability theory share the view that global order can be achieved through international institutions only if one or more dominant hegemons have power or political will to enforce a system that benefits them (Krasner 1976; Gilpin 1987). Small states, according to this perspective, would comply with the imposed rules by a hegemon unless they intend to challenge the hegemonic power(s).

Neoliberal institutionalism, originated with Keohane's After Hegemony, responded to this pessimistic view of international politics by demonstrating that states can cooperate on a range of issues. They recognize that states might willingly construct norms and institutions to regulate their behavior because doing so will enhance their long-term interests. International institutions can facilitate cooperation by providing participants with mutual (economic) gains if they are designed such that cooperation, and not defection, is in participants best interest (Martin and Simmons 2013, 331). They view sanctions or penalties as the leading cause of states' compliance.

The institutional transformation is not conceivable in those two rationalist' approaches. Both hegemonic stability theory and neoliberal institutionalism assume that preferences do not change; the material power is asocial in the sense that its potential change as a consequence of interactions with other states is dismissed. They "make parsimonious assumptions about what all states want: states are assumed to want some combination of power, security, and wealth" (Finnemore 1996, 1). As Keohane (1988) admitted, "rationalistic theories are incomplete since they ignore changes taking place in consciousness. They do not enable us to understand how interests change as a result of changes in belief systems" (Keohane 1988, 391). Nonetheless, as Johnston (2001, 496) argues, "holding preferences constant for the purpose of modeling prevent one from exploring this important issue."

In contrast, Social Constructivists and English School scholars emphasize the importance of interactions in "international society" (Bull 1977, 1). They situate international institutions in the context of social setting where actors can shape the nature of the society as well as the nature of its own and other actors through their interactions. In other words, the anarchic nature of international politics that the rationalists believe is something that members of society can change (Wendt 1992; Martin and Simmons 2013, 333-334). This social aspect of the potential transformation of conflictual interstate relationships makes socialization possible. States switch from following the logic of consequences to 
a logic of appropriateness; this shift is sustained over time and is independent of a particular structure of material incentives or sanctions.

Constructivists believe that norms can change the actors' identities, which then can lead to changes in their preferences and interests. That is, social constructivism allows the possibility of change in preferences, which can lead to the internalization of norms, or the institutional transformation. Nevertheless, not every norm reaches the stage of the institutional transformation. Constructivists have specified stages of norm-diffusion. Johnston's mimicking and social influence (Johnston 2008, 23-25), or the Type I socialization, or role-playing in Checkel $(2005,810-812)$, can occur without the institutional transformation, while persuasion as in Johnston (2001, 496-499) is dealing with the institutional transformation.

English School scholars elaborate on the relation between power and norms promoted by international society, including international institutions. States may voluntarily abide by the norms when they seek status or legitimacy in international society (Bukovansky et al. 2012, 50, 63-64). According to them, "legitimacy is constitutive of social power" (Clark 2014, 325), and legitimacy is granted when states take the responsibilities allocated based on their material power (Bukovansky et al. 2012, 7). Thus, norm-compliance can play a powerreinforcing role.

Each theory suggests factors that determine states' position on compliance: hegemon's coercion, economic benefits, aspirations for legitimacy, reputational costs, and preference change. Based on these theories, five propositions regarding institutional transformation can be stated:

Proposition HST: If there is institutional transformation, states comply in the absence of the pressures from a hegemon. (That is, compliance due to pressures from a hegemon does not indicate institutional transformation)

Proposition NI: If there is institutional transformation, states comply even if the economic costs of compliance are higher than the economic benefits of compliance. (That is, compliance due to larger economic net benefit does not indicate institutional transformation)

Proposition SC-1: If a state complies even if the economic costs are larger than the benefits of complying because of peer pressure, then socialization has begun, but the institutional transformation has not taken place.

Proposition SC-2: If a state voluntarily complies in the absence of economic net benefits and peer pressure, then institutional transformation has taken place. 
Proposition E.S.: Status- or legitimacy-seeking states have incentives to comply with international norms, irrespective of their position in the global hierarchy, or cost-benefit calculation of compliance.

The Propositions identify the causal factors that each theory puts forward concerning norm-compliance and institutional transformation. Examining the presence of such factors and states' behavior, both of which are observable, will provide the information on whether the unobservable institutional transformation has taken place or not. Based on the propositions, the presence of a benevolent hegemony, economic cost-benefit calculation, and the presence of reputational pressure, together with states' behavior, are used to judge whether the institutional transformation has taken place. As with Ikenberry and Kupchan $(1990,286)$ or Dobbin, Simmons, and Garrett $(2007,464)$, I assume no single paradigm is predominant in explaining the reality, but I aim to clarify to what extent each paradigm has explanatory power under what conditions.

In practice, empirical findings often reveal only partial support for existing theories in that one can only conclude that theory holds under certain conditions or to a certain degree (George and Bennett 2005, 6). Nonetheless, as Johnston (2001) contends, "separating them out is important because the answer will help point to how durable pro-social conformity is over time and what kinds of institutional designs are most conducive to this durability" (p. 496). Likewise, identification of the factors that facilitate or hinders climate action can help to assess the potential of the global climate governance system. Therefore, this paper applies the Propositions to examine which theories have explanatory power, and further investigates alternative potential causal factors for norminternalization.

The theories covered in this section treat states as a unitary actor or at least do not present a well-developed model for linking domestic circumstances with the decisions at the international level. Nevertheless, whether and how the central government's (i.e. the state's) international pledges are domestically implemented depends on "domestic structures," which refer to "the political institutions of the state, to societal structures, and to the policy networks linking the two" (Risse 1995, 20). In the discussion of the domestic contexts of the U.S. and China, major domestic actors' preference changes, and how they translate into policy implementations through domestic institutional features will be addressed. Public surveys, statements of politicians or government leaders, and actions taken by firms are used as measures of preference change of domestic actors. It is noteworthy that the complications with treating states as unitary actors in the discussion of unobserved aggregated states' preferences disappear with domestic actors when measures of their preference exist. 


\section{US AND CHINA CASES}

Ever since 1992, when the UNFCCC was created, the U.S.'s positions at the international climate negotiations have oscillated with the change of administrations. President Clinton signed the Kyoto Protocol, but President Bush repudiated it; President Obama played a vital role in Copenhagen in 2009 and signed the Paris Agreement in 2015, but President Trump announced its intention to withdraw from it in 2017. On the other hand, China's position in climate change has been increasingly accomodating to the international norms, with its leadership's public endorsement of climate action even after the U.S.'s announcement of withdrawal.

In contrast with the international positions of the U.S. and China, domestic implementation shows different patterns. Currently, emissions in the United States remain around their 1990 levels, recording the largest emissions decline among all countries in 2018 and 2019 consecutively (EIA 2019a, 10; IEA 2020), while China increased coal production capacity in the face of economic slowdown (Stanway and Xu 2019). Despite the progress in emission level, the U.S. decided to pull back from the Paris Agreement; despite the economic challenges, China continues to commit to ambitious climate action. What is puzzling is why there exist differences between the rhetoric in the international stage and domestic action.

In the discussion of the prospects for the socialization of the Paris Agreement, understanding why the discrepancy exists in the top two emitters is important. The U.S. and China are significant, not only in terms of their massive emissions levels. The evolution of global climate governance has also shown their instrumental roles in climate norm creation. In the first place, the shift of global climate governance paradigms to the "pledge and review" regime, despite the opposition from some European countries, small island countries, and environmental activists, was made possible by the resistance by China (in coalition with other emerging countries) as well as the lukewarm stances taken by the U.S. at the Copenhagen. Moreover, the breakthrough was also made by the U.S.'s and China's bilateral agreement (White House 2014) in 2014 in the run-up to the Paris conference. Then again, President Trump's announcementof the U.S.'s withdrawal in 2017 damaged the momentum created at the Paris conference. Therefore, the norm-internalization in the two countries may boost the successful operation of the Paris climate regime.

This section discusses to what extent existing theories explain the discrepancies observed in the U.S. and China and draws on lessons on the potential of the Paris Agreement by investigating their domestic contexts and by identifying domestic factors of the discrepancies. 


\section{Institutional transformation of states?}

The propositions treat states as unitary actors. Therefore, the causal factors the presence of a hegemon, economic costs and benefits, and reputational pressures - are also measured at the state level. Aggregate economic costs and benefits calculation is done, and the reputational pressures are put on the government policymakers. This subsection discusses the propositions in terms of both international commitments and domestic implementation.

For the discussion of the Propositions, the three causal factors need to be identified. The first of them, a benevolent hegemon, is believed not to exist in the issue of climate change. When it comes to economic cost-benefit analysis, in the short run, implementing emissions reductions is costly in both countries. The U.S. and China, currently account for $15 \%$ and $28 \%$ of global total $\mathrm{CO} 2$ emissions, respectively (Sandalow 2019, 11). China has remained the largest producer and largest user of coal after peaking in 2013. Coal accounts for around $60 \%$ of China's electricity generation (EIA 2020, 103); as of the share of fossil fuels accounted for around $80 \%$ of the U.S. energy consumption (EIA 2018). In the long-run, nonetheless, both countries may be able to reap the benefit of investing in renewable industries as the top two leaders of the renewable energy industries. China, with the $\$ 83.4$ billion of investment in the renewable sector in 2019 has been leading the industry, followed by the U.S. with $\$ 55.5$ billion in the same year (FS-UNEP 2019, 22). The projection up to 2050 shows the potential for the expanding market for renewables, with renewable energy growing fastest, to take around $28 \%$ of total world consumption in 2050 (IEA 2020, 31). That is, although $\mathrm{CO} 2$ emissions reductions measures are costly in the short run, investing in renewables can bring benefits in the future. For the discussion of propositions, however, only short-run economic net benefits will be considered as the long-term benefits are uncertain.

The reputational pressures by naming and shaming from peer party states and Transnational Advocacy Networks (Keck and Sikkink 1998) have been on the rise, as can be seen in the massive 'global climate strikes' during a U.N. conference in September 2019. Moreover, the priorities of the G77 countries began to diverge as climate action or inaction clashes with each country's economic potential. The interests of fossil fuel producers conflict with those of small islands countries; the LDCs and AOSIS share the views on the CBDR/RC principle, as well as the right to develop and seeking financial and technological assistance, but they demand all emitters, including BASIC countries to help with mitigation of greenhouse gas emissions (Hochsteteler, 2012, 61). Nevertheless, such pressures have been put on policymakers of the central governments and firms operating overseas, and it is less likely that subnational policymakers nor other domestic actors are influenced by such peer pressure unless they involve in 
international networks.

Based on the information on the causal factors, the propositions can be applied to both international commitments and domestic emission reductions. Firstly, international commitments to climate norms are considered for an outcome for sustained compliance. As the U.S.'s positions for international commitment to climate action have been oscillating, nothing can be said about the U.S.'s institutional transformation based on Proposition HST. On the other hand, institutional transformation in China may have occurred as China has changed its position on climate change and has committed to taking more role, without the coercion from a hegemon. Likewise, Proposition NI is not useful in judging the U.S.'s institutional transformation as the U.S. decided to withdraw, while institutional transformation may have taken place in China as China has changed its position despite the economic costs in the short run. Propositions SC-1 and SC-2 also point to the same conclusion that institutional transformation has not occurred in the U.S. when considering the U.S.'s commitments to international climate norms. For China, Proposition SC-2 does not apply to China, as there have always been peer pressures when it comes to climate change, but Proposition SC-1 implies that institutional transformation may have begun as China changed its position in the international climate negotiations and has kept its position.

Then next, by applying the same logic as the case for the international commitments, when applying Propositions to domestic progress of emissions reductions, the opposite conclusions will be reached. In other words, the existing theories are not very useful in judging the potential for institutional transformation. This points to the limitations of state-centric international relations theories on international cooperation under the regimes without enforcement mechanisms. Different domestic actors may feel the costs and benefits as well as the reputational pressures differently, and there can be discrepancies in states' international and domestic responses. In the next subsections, the domestic circumstances of the U.S. and China will be examined to find out possible explanations for the discrepancies of their international and domestic behaviors.

\section{U.S. 's domestic context}

The negotiation processes demonstrate the adamant stance of the U.S. against the targets and timetables and the exemption of the emerging countries from responsibilities. It was only after 2013 when the Obama administration began to engage with China actively that the U.S.'s position changed in the negotiation table. Nonetheless, President Trump announced the U.S.'s withdrawal from the Paris Agreement in 2017 and issued the final Affordable Clean Energy (ACE) rule in 2018 in replace of Obama's Clean Power Plan (CPP) (UNEP 2019, 
20). This shift in the international arena can only be explained when domestic contexts are taken into consideration.

In the U.S., "concerns over energy security and sustained low energy prices overshadowed concerns for environmental protection" (Bang 2015, 163). Existing studies argue that the U.S.'s foreign policy on climate change has been shaped by electoral disincentives, reinforced by the U.S.'s distinctive political institutions (Harrison 2010; Bang 2015). This paper argues that the U.S.'s withdrawal is a result of a lack of societal demand for climate action. Nonetheless, this paper observes that positive changes take place at the subnational level that has led to progress in reducing emissions.

First of all, Congressional opposition is the result of the institutional feature combines with the economic structure. The U.S. economy has heavily relied on abundant resources. As of 2018, coal (13\%), oil (36\%), and natural gas (31\%) account for around $80 \%$ of total energy consumption (EIA 2019a). Coal takes only $13 \%$ of total energy source (EIA 2019a) in the U.S., with mining activities generating jobs and income in more than 26 states (EIA 2019c), in contrast with oil, $80 \%$ of whose reserves are concentrated in four states (Bang 2015). This implies that 52 senators represent constituencies whose welfare is linked to the production of coal. This economic structure has rendered the Congress represents the interests of their constituents, rather than the Party principle, which is why any federal measures through legislation have failed to pass Congress (Bang 2015, 163). Besides, the U.S. Congress passed the Byrd-Hagel Senate Resolution unanimously in 1997, which states that the U.S. should not sign a treaty unless it requires developing countries to take equal responsibilities. To avoid the need to go through Congress, the Obama administration had to push the idea of "voluntary" guidelines instead of binding rules in the negotiations leading to the Paris conference (Obergassel et al. 2015).

Given the fixed nature of institutions and the state-society relation in the U.S. over the past decades, a breakthrough can happen only when changes in societal demands from the businesses and the public occur. In other words, although the political institutions would remain the same, Congressional opposition may change if demands from the society, or the economic structure, or both change. In the U.S., the fossil fuel-intensive economic structure and the business interests began to change, while the public views have remained divided.

The coal industry began to lose its hold. Most U.S. coal is consumed in the electric power sector, where it has faced increased competition from electricity generation from natural gas and renewable technologies. Accordingly, the U.S. coal mining employment fell from a high of 92,000 employees in 2011 to 54,000 employees in 2018, with the most dramatic decrease in the Appalachian region (EIA 2019b). 
Also, the industrial hostility became less fierce, albeit still divided, as a result of the active environmental movement over the years and its realization for future profit from the new operating environment. Initially, in the early 1990s, the businesses were unified. The U.S. business community, led by trade associations, including the American Petroleum Institute, the U.S. Chamber of Commerce, and the National Association of Manufacturers, as well as the cross-sectoral Global Climate Coalition, presented strong and untied opposition to climate policies and ratification of the Kyoto Protocol. American business argued that international treaties would hinder the competitiveness of the U.S. economy (Harrison, 2010, $69)$.

This began to change. As early as 1998, BP and Shell both withdrew from the Global Climate Coalition (GCC), followed over the next two years by Ford, Daimler Chrysler, GM, and Texaco (Harrison 2010, 70). Also, ExxonMobil and Shell backed down to public boycott due to human rights violations in Nigeria and deep-sea disposal for Shell, and oil spill for ExxonMobil (Skjærseth \& Skodvin, 2001). Corporate leaders increasingly worried that opposition to reductions in GHG emissions was hurting their public images. Also, several companies came to the conclusion that there were potential profits available through the creation of a domestic market in GHG emission credits. Businesses have to adjust as more states decide to put environmental regulations, as can be seen in the deal with California (Van Sant 2019).

In contrast, the U.S. public views on climate change have been very slowly changing (Egan and Mullin 2017). It has been well documented that the U.S. public attitudes towards climate change were deeply divided: Democrats and liberals are more likely to believe the scientific evidence about Anthropogene climate change than Republicans (McCright and Dunlap 2011; Egan and Mullin 2017, 216). According to the Pew Research Center poll (Pew Research Centre 2018), 36\% of Americans are personally concerned about climate change, among which $72 \%$ are Democrats. The same poll shows that the percentage of U.S. adults who say climate change (or global warming) is a top priority for the President and Congress is increasing over time among Democrats, the percentage of those Republicans who say so do not change over time.

That is, the increase in awareness of climate issues has not led to a change in policy prioritization among the Republicans. Intensifying global discussion over climate change and environmental activism in the U.S. has raised the awareness of the issues, yet there is no evidence of long-term change towards a belief in human-induced global warming (Egan and Mullin 2017, 213). Education and science comprehension are positively related to the belief among Democrats and liberals, while they are weak among Republicans and conservatives (Egan and Mullin 2017, 216), which implies providing more information and attempts to persuade will do have little effect to the latter groups. 
Given the changes in economic structure and less fierce hostility of the business, both of which work towards more favorable climate action, the shifts in position from the Obama administration and Trump administration should be explained by the still partisan division of the public attitudes towards climate action. Republicans or the conservatives have not been changing their attitudes towards human-induced global warming, regardless of their demographic characteristics, which provides little incentives for climate action with the President they support.

The changes in some of the business's positions and limited changes in public preferences over climate action demonstrate the importance of domestic actors in shaping the position of the state (the central government) in climate negotiations. When climate change has not taken the highest political agenda, the administration has an incentive to take the view of their supporters. Likewise, changes at the subnational level highlight the bottom-up approach as a potential solution, and this is also explained by the subnational government's incentives to reflect their voters, resulting in Partisan differences across states and cities climate implementation. Despite the deadlock in the U.S. society, the Obama administration's domestic mechanism of CPP allowed for the room for climate policies at the subnational level despite the resistance of national Congress. The CPP has opened up the possibility of introducing more radical climate policies in states that are free from fossil-fuel related economic constraints. Recently, California has formed a deal with four Four of the world's largest automakers, Ford, BMW, Honda, and Volkswagen, to produce fuel-efficient cars (Van Sant 2019), although the Justice Department has also launched a probe to see whether this violates antitrust laws (Booker and Ludder 2019).

This points to a potential avenue of change despite the contention on actual impact (Karapin 2020). Divided publics have only limited impacts on the federal government's position, but Democrats-governed state-level regulations have started to change the business environment. As the Paris Agreement has set the tone of the future business environment with expanding renewable energy markets, actors in the business sector may have been changing their long-term strategies. This can explain the discrepancies in the U.S.'s international commitments and domestic implementation.

\section{China's domestic context}

China presents a compelling case for the role of international institutions in socializing states into internationally agreed norms. Nevertheless, China's ambitious climate action plans are not matched with actual domestic implementation. In this subsection, this will be explained by a response to both economic benefits and reputational pressure to status-seeking Chinese leaders, if 
not of the institutional transformation, as well as the lack of capacity for subnational governments to meet the targets set by the central government, which is the result of the institutional feature of decentralization in China. Although the Paris Agreement was reached in 2015, the Chinese leaders and domestic actors showed a change in their positions on climate change before then. This paper notes that understanding the process of such changes can help to identify the factors that facilitate or block domestic progress.

China started to participate in the international discussion on climate change as early as 1972 at the Stockholm conference, where it actively advocated the position of the developing South for their right to develop (Foot and Walter 2011, 177-180). Nonetheless, economic growth has been China's highest priority. China perceives climate change as an "issue involving both environment and development, but it is ultimately an issue of development" (NDRC 2007). China argued that the burden should be proportional to historical emissions and contended that developing countries should be allowed to use fossil fuels for their survival, and people in the advanced countries should adjust the level of emissions to maintain their lifestyle (Foot and Walter 2011, 186-192). This understanding has shaped China's positions in international negotiations that developed countries need to change their consumption paths to reduce GHG emissions and that developing countries should be given necessary technical and financial support to adapt themselves.

This tendency continued up until 2007, a tipping point in climate change. While the Stern Report on the economics of climate change argued that the likely costs of inaction far outweigh the costs of the action, the $4^{\text {th }}$ IPCC report influenced the $13^{\text {th }}$ Conference of Parties meeting held in Bali in 2007, where China compromised some of its previous positions (Christoff 2010, 651). Most significantly, this was the year when China overtook the U.S. and has become the world's largest $\mathrm{CO} 2$ emitter. With the mounting evidence of the damaging effects of global warming and rapidly increasing GHG emissions by developing countries, the Kyoto Protocol approach where non-Annex I countries had been exempt from emission reduction obligations became less tenable. Nonetheless, they continued to refuse to commit to legally binding "targets and timetables" obligations by then.

Amid fast economic growth, nevertheless, Chinese leaders and elites began to recognize the economic growth strategies relying on coal-intensive industries and cheap labor would not be sustainable (Green and Stern 2017, 424-427; Hilton and Kerr 2017, 50). Hilton and Kerr (2017) argued that the drastic shift in China's position from Copenhagen to Paris was because China's preparation for the economic restructuring granted China more room to take climate action. Hilton and Kerr (2017) were right in that the $12^{\text {th }}$ Five-Year Plan (FYP) (2011-2015) advanced the economic restructuring to depart from the 
coal-intensive economy, including the promotion of the renewable industries. It is also true that China has been successful in reducing the growth of emissions and has become a world leader in renewable energy investment (World Bank 2013, 226; IEA 2020, 19-20) and has the potential to become a world leader in critical green technologies and business models (World Bank 2013, 221-222). Nonetheless, being at an early stage of industrialization and urbanization, China's addressing its environmental issues will increase industrial costs and a slowdown of economic growth (World Bank 2013; Feng 2018). Indeed, China's energy regulator approved to build 141 million tonnes of new annual coal production capacity from January to June 2019, a five-fold increase compared to last year, in the face of slowing economic growth (Stanway and Xu 2019).

Despite the economic burdens, China, for the first time in Copenhagen, agreed to commit and to be under "domestic" measurement, reporting and verification (MRV) in international consultation, which was one of the contention points with the U.S. in Copenhagen. China compromised, although it still stuck to the principle of "not sacrificing its sovereignty to outside verification" (Christoff $2010,644)$, and rejected the targets and timetables approach. This can hardly be viewed as a decision due to economic benefits. Even as of 2018, China's economic structure has not reached the status that can benefit from climate action, when coal is still China's top energy source (Feng 2018; IEA 2019, 16), and carbon intensity is the highest (Sandalow 2019, 15).

Given this, the fact that China agreed to take responsibility and to be reviewed on its progress on climate action in Copenhagen requires other explanations than those based on economic benefits. This paper argues that Chinese leaders also have been influenced by the global normative framework (Foot and Walter 2011, 199), possibly because complying with the norm is in its best interest in non-material terms.

The Chinese Communist Party (CCP) faced a demand from the domestic public for action to address pollution. Despite China's media and internet control, the public became more aware of the health concerns caused by pollution. For example, in 2015, a former CCTV journalist, Chai Jing, made a documentary, "under the dome," the potential damage that China's air condition could bring to the public health (Ren, 2015). Although the film was banned immediately, it made a massive impact on people's awareness of the issue. The Chinese political system does not allow public participation in policymaking, yet the CCP concerned about domestic stability and its legitimacy, which has made the CCP respond to public demands for potentially competing goals. China faces a dilemma that it has to achieve sustained economic growth to justify the communist ruling. At the same time, it has to meet the demand from society for quality life, including clean air and water (Christoff 2010, 645).

Also, China was under increasing external pressure to take more climate 
action as a "responsible stakeholder" (Shambaugh 2013, 102-105). Moreover, it began to realize the need to be seen as a responsible actor in the international community. Despite the earlier skepticism within China regarding China's capability to provide global public goods, criticism on China's free-ride began to rise as China emerged rapidly as an economic power. Besides, the G77 countries broke rank in the negotiation table, weakening the position of China.

President $\mathrm{Hu}$ (2007) was the first Chinese high official who endorsed the importance of public diplomacy and soft power - an ability to make other countries want to emulate the example (Nye 2004, 5). However, China's aspirations for more soft power and to be respected as a responsible great power were more boldly stated after President Xi became President in 2013. While President $\mathrm{Xi}$ announced the underlying theme of China's diplomacy in terms of the need to pursue development and national interests, he stressed China's intention to "seek other countries' understanding of and support for China Dream" (Swaine 2015, 5). Also, at the 2014 APEC, Xi said that as "its overall national strength grows, China will be both capable and willing to provide more public goods for the Asia-Pacific and the World" (Xi, 2014). During the $18^{\text {th }}$ National Congress of the Communist Party of China in 2014, President Xi remarked that "we should increase China's soft power, give a good Chinese narrative, and better communicate China's messages to the world." President Xi also noted that "being a big country means shouldering greater responsibilities for regional and world peace and development" $(\mathrm{Xi}, 2015)$.

As Joseph Nye put it, wielding soft power is harder because it requires "acceptance by the receiving audience" (Nye 2004, 99). The "receiving audience" can influence China's material interest, not only its image. They can exercise power over China as a consumer of Chinese goods, or as a voter in their own country, by which the success of Chinese flagship projects such as BRI could be affected. In this sense, taking climate leadership could benefit China by boosting its image, which may also lead to material returns. Indeed, President Xi colored the BRI with more acceptable green initiatives by calling for "an international coalition for green development on the Belt and Road" (Sandalow 2019, 128) at the First Belt and Road Summit in May 2017. That is, the power that the Chinese leaders seek is social power that English School scholars view to be granted by others. China's willingness to take a leadership role can be understood in this regard.

Nonetheless, all this is driven by the central government, but the implementation of centrally planned targets rests on subnational governments under the Chinese decentralized system. In contrast with the initial discussion on environmental authoritarianism, China's top-down "command and control" governance system was described to be "command without control" (Kostka 2016) with a lack of enforcement effectiveness at the local level. It has been 
argued to be due to the central-local relations with administrative centralization and fiscal decentralization. The centrally created environmental laws and targets failed to be implemented locally, because "China's fiscal structure and cadre performance evaluation system have provided incentives for poor regulatory enforcement, delayed policy implementation, and widespread shirking of environmental laws at subnational levels" (Kostka and Nahm 2017, 2).

In conclusion, the discrepancies between the international pledges and domestic implementation can be explained by the decentralization system of China under which central and local leaders' incentives may not be aligned. Besides, the capacity to meet the targets set by the central government across regions varies with poor regions still needing to rely on cheap fossil fuels. China, as a strong CCP-led country, appears to be an example in which the state-centric international relations approaches work well, yet, looking into domestic contexts, the puzzle of international and domestic discrepancies can be explained by incorporating domestic structures and incentives of different domestic actors.

\section{CONCLUSION: DOMESTIC CONTEXTS AND SOCIALIZATION}

This paper explores the prospects of the Paris Agreement for socializing states into the internationally agreed climate norm by examining why the discrepancies between international committments and domestic action exist in the U.S and China. This paper reached the following conclusions.

Firstly, this paper contends that domestic contexts need to be examined to explain states' behavior, by showing the limitations of existing theories and finds that (i) the divided public attitudes towards human-induced global warming and the unchanging public prioritization are one of the reasons for the oscillation of the federal government negotiation positions; while subnational governments can implement climate policies if their constituents demand so; (ii) the status- and legitimacy-seeking China has had incentives to take the leadership role in climate action, even at the cost of the immediate economic loss at the international stage, yet the decentralization features of China have caused the local-central leaders' incentive to be misalignment, resulting in patchy local achievements of climate targets set by the central government.

Secondly, the paper notes that in the absence of enforcement mechanisms, each party state needs to pledge ambitious enough targets and to voluntarily implement them domestically. Domestic governance systems and institutional features may determine which domestic actors' preferences translate into domestic policies. The federal system in the U.S. facilitates subnational implementation in the regions with strong climate demands from voters, while in China, the decentralized system has blocked the progress in climate action in 
particular, in poor regions.

Thirdly, this paper finds that the lack of enforcement mechanisms internationally (and domestically as well, in the U.S. and China cases), socialization, or norm-internalization from the bottom-up, may be more effective. On the one hand, both the U.S. and China governments - central and subnational, - need to respond to societal demands, to win in the elections and stay in power in the U.S. and to keep domestic stability in China. On the other hand, the factors that are identified by existing state-centric theories, economic incentives and reputational pressures can be also important for some domestic actors, yet different domestic actors respond to economic and reputational pressures differently. Therefore, to make policymakers implement climate policies domestically, one might conclude that the targets of socialization should be societal actors, rather than "states and individual policymakers" as Checkel argues (Checkel 2005, 804).

\section{REFERENCES}

Bang, Guy. 2015. "The United States: Obama's Push for Climate Policy Change." Pp 160-181 in The Domestic Politics of Global Climate Change, (Eds) G.Bang, A.Underdal, and S. Andresen. Cheltenham: Edward Elgar.

Bodansky, Daniel. 2010. "The Copenhagen Climate Change Conference: a Postmortem." American Journal of International Law 104(2): 230-240.

Bodansky, Daniel. 2016. "The Paris Climate Change Agreement: a New Hope?" American Journal of International Law 110(2): 288-319.

Booker, Brakkton and Jennifer Ludden. 2019. "Trump Administration Challenges

California And Automakers On Fuel Economy,” accessed March 10, 2020, https://www.npr.org/2019/09/06/758388036/trump-administration-challeng es-california-and-automakers-on-fuel-economy

Bukovansky, Mlada, Ian Clark, Robyn Eckersley, Richard Price, Christian Reus-Smit, and Nicholas Wheeler. 2012. Special Responsibilities: Global Problems and American Power. Cambridge: Cambridge University Press. Bull, Hedley. 1977. The Anarchical Society: A Study of Order in World Politics. London: Macmillan.

Carrington, Damian. 2020. "Heathrow Third Runway Ruled Illegal Over Climate Change.” The Guardian, accessed March 10, 2020, https://www. theguardian. com/environment/2020/feb/27/heathrow-third-runway-ruled-illegal-over -climate-change

CAST. 2019. "Two-theirds of People Support Limiting Air Travel to Tackle Climate Change," Center for Climate Change and Social Transformations, Cardiff University, accessed May 25, 2020, https://www.cardiff.ac.uk/ 
news/view/1591846-two-thirds-of-people-support-limiting-air-travel-to-ta ckle-climate-change

Checkel, Jeffrey. 2005. "International Institutions and Socialization in Europe: Introduction and Framework." International Organization 59(4): 801-826.

Chiu, Dominique. 2017. "The East is Green: China's Global Leadership in Renewable Energy," New Perspectives in Foreign Policy 13.

Christoff, Peter. 2010. "Cold Climate in Copenhagen: China and the United States at COP15." Environmental Politics 19(4): 637-656.

Christoff, Peter. 2016. "The Promissory Note: COP 21 and the Paris Climate Agreement." Environmental Politics 25(5): 765-787.

Clark, Ian. 2014. "International Society and China: the Power of Norms and the Norms of Power." The Chinese Journal of International Politics 7(3): 315-340.

Dobbin, Frank, Beth Simmons, and Geoffrey Garrett. 2007. "The Global Diffusion of Public Policies: Social Construction, Coercion, Competition, or Learning?” Annual Review of Sociology 33: 449-472.

Egan, Patrick. and Mullin, Megan. 2017. "Climate Change: U.S. Public Opinion." Annual Review of Political Science 20: 209-227.

EIA. 2019a. International Energy Outlook 2019. U.S. Energy Information Agency

EIA. 2019b. "U.S. Coal Production Has Fallen by 42\% since 2011." accessed March 10, 2020, https://www.eia.gov/todayinenergy/detail.php?id=42275

EIA. 2019c. "U.S. energy facts explained." accessed March 10, 2020, https://www.eia.gov/energyexplained/us-energy-facts/

Falkner, Robert. 2016. "The Paris Agreement and the New Logic of International Climate Politics.” International Affairs 92(5): 1107-1125.

Feng, Emily. 2018. "Beijing Axes Coal and Steel Production Curbs as Economy Slows" The Financial Times, accessed March 10, 2020, https://www.ft.com/ content/3bf1dde2-c2ec-11e8-95b1-d36dfef1b89a

Finamore, Barbara. 2018. Will China save the planet? New Jersey: John Wiley \& Sons.

Finnemore, Martha. 1996. National Interests in International Society. Cornell University Press

Finnemore, Martha and Kathryn Sikkink. 1998. "International Norm Dynamics and Political Change.” International Organization 52(4): 887-917.

Foot, Rosemary and Andrew Walter. 2011. China, the United States, and Global Order. Cambridge: Cambridge University Press.

FS-UNEP. 2019. Global Trensd in Renewable Energy Investment 2019. Frankfrurt School-UNEP Center.

George, Alexander and Andrew Bennett. 2005. Case Studies and Theory Development in the Social Sciences. Cambridge: MIT Press. 
Gilpin, Robert. 1987. International Political Economy. Princeton: Princeton University Press.

Green, Fergus and Nicholas Stern. 2017. "China's Changing Economy: Implications for its Carbon Dioxide Emissions." Climate Policy 17(4): 423-442.

Harrison, Kathryn. and Lisa Sundstrom. 2010. Global Commons, Domestic Decisions: The Comparative Politics of Climate Change. Cambridge: MIT Press.

Hate not Hope. 2019. Climate Change Won't Just Cause Extreme Weather, But Extreme Politics, accessed May 25, 2020, https://www.hopenothate.org.uk/ 2019/09/20/climate-change-wont-just-cause-extreme-weather-but-extreme -politics/

Hilton, Isabel and Oliver Kerr. 2017. "The Paris Agreement: China's 'New Normal' Role in International Climate Negotiations." Climate Policy 17(1): 48-58.

Hochstetler, Kathryn. 2012. "The G-77, BASIC, and Global Climate Governance: a New Era in Multilateral Environmental Negotiations." Revista Brasileira de Política Internacional 55(SPE): 53-69.

Hooghe, Liesbet. 2005. "Several Roads Lead to International Norms, but Few via International Socialization: A Case Study of the European Commission." International Organization 59(4): 861-898.

Hu, Jintao. 2007. Report to the $17^{\text {th }}$ Party Congress of the Chinese Communist Party (October 15 207).

IEA 2020. Global emissions CO2 emissions in 2019. accessed March 10, 2020, https://www.iea.org/articles/global-co2-emissions-in-2019

Ikenberry, John and Charles Kupchan. 1990. "Socialization and Hegemonic Power." International Organization 44(3): 283-315.

Johnston, Alastair. 2001. "Treating International Institutions as Social Environments." International Studies Quarterly 45(4), 487-515.

Johnston, Alastair. 2008. Social states: China in International Institutions, 1980-2000. Princeton University Press.

Karapin, Roger. 2020. "Federalism as a Double-Edged Sword: The Slow Energy Transition in the United States." The Journal of Environment \& Development 29(1), 26-50.

Keck, Margarett and Kathryn Sikkink. 1998. Activist Beyond Borders: Advocacy Networks in International Politics. Ithaca: Cornell University Press.

Keohane, Robert. 1984. After Hegemony. Princeton: Princeton University Press.

Keohane, Robert. 1988. "International Institutions: Two Approaches." International Studies Quarterly 32(4): 379-396.

Keohane, Robert. and Michael Oppenheimer. 2016. "Paris: Beyond the Climate Dead End through Pledge and Review?" Politics and Governance 4(3): 142-151.

Kostka, Genia. 2016. "Command without control: The case of China's environmental 
target system." Regulation \& Governance 10(1): 58-74.

Kostka, Genia and Jonas Nahm. 2017. "Central-local relations: recentralization and environmental governance in China." The China Quarterly 231: 567-582.

Krasner, Stephen D. 1976. "State Power and the Structure of International Trade." World Politics 28(3): 317-347.

Laville, Sandra. 2020. "Heathrow runway ruling prioritises planet over needs of U.K. plc.” The Guardian, accessed March 10, 2020, https://www.theguardian.com/ environment/2020/feb/27/heathrow-runway-ruling-puts-planet-over-needs -of-uk-plc.

Martin, Lisa and Beth Simmons. 2013. "International Organizations and Institutions." Handbook of international relations 2: 326-351.

McCright, Aron and Reiley Dunlap. 2011. "The Politicization of Climate Change and Polarization in the American Public's Views of Global Warming, 2001-2010." The Sociological Quarterly 52(2): 155-194.

National Development and Reform Commission. 2007. "China's National Climate Change Programme"

Nye, Joseph. 2004. Soft power: The Means to Success in World Politics. New York: Public affairs.

Obergassel, Wolfgang., Christof Arens, Lukas Hermwille, Nico Kreibich, Florian Mersmann, Hermann Ott, and Hanna Wang- Helmreich. 2015. "Phoenix from the Ashes: an Analysis of the Paris Agreement to the United Nations Framework Convention on Climate Change; part 1." Environmental Law and Management 27: 243-262.

Obergassel, Wolfgang., Christof Arens, Lukas Hermwille, Nico Kreibich, Florian Mersmann, Hermann Ott, and Hanna Wang- Helmreich. 2016. "Phoenix from the ashes: an analysis of the Paris Agreement to the United Nations Framework Convention on Climate Change; part II." Environmental Law and Management 28: 3-12.

Pew Research Center 2018. Economic Issues Decline Among Public's Policy Priorities. Accessed March 10, 2020, https://www.people-press.org/2018/ 01/25/economic-issues-decline-among-publics-policy-priorities/

Ren, Yuan. 2015. Under the Dome: will this film be China's environmental awakening? The Guardian, accessed March 10, 2020, https://www.theguardian. com/commentisfree/2015/mar/05/under-the-dome-china-pollution-chai-jing

Risse, Thomas. 1995. Bringing Transnational Relations Back In: Non-State Actors, Domestic Structures and International Institutions. Cambridge: Cambridge University Press.

Sandalow, David. 2019. Guide to Chinese Climate Policy 2019. Columbia: Center on Global Energy Policy. Columbia SIPA.

Shambaugh, David L. 2013. China Goes Global: The Partial Power. Oxford: 
Oxford University Press.

Skjærseth, Jon and Tora Skodvin. 2001. "Climate change and the oil industry: Common problems, different strategies." Global Environmental Politics, 1(4), 43-64.

Snidal, Duncan. 1985. "The Limits of Hegemonic Stability Theory." International organization 39(4): 579-614.

Stanway, David and Minyu Xu. 2019. "China Coal Mine Approvals Surge Despite Climate Pledges." Reuters, accessed March 10, 2020, https: //www.reuters.com/article/us-china-coal-climate/china-coal-mine-approval s-surge-despite-climate-pledges-idUSKCN1UW0EM

Swaine, Michael D. 2015. "Xi Jinping's Address to the Central Conference on Work Relating to Foreign Affairs: Assessing and advancing major-power diplomacy with Chinese characteristics." China Leadership Monitor, 46(1).

UNEP. 2019. The Emissions Gap report 2019: A UNEP synthesis report. Nairobi: United Nations Environment Programme

UNFCCC. 1992. United Nations Framework Convention on Climate Change. Accessed March 10, 2020, https://unfccc.int/resource/docs/ convkp/conveng.pdf

UNFCCC. 1997. Kyoto Protocol to the United Nations Convention on Climate Change Accessed March 10, 2020, http://unfccc.int/resource/docs/convkp/ kpeng.pdf

UNFCCC. 2015. Paris decision. FCCC/CP/2015/L.9/Rev.1. Accessed March 10, 2020, https:/unfccc.int/resource/docs/2015/cop21/eng/109r01.pdf

Van Sant, Shannon. 2019. "California Signs Deal With Automakers To Produce Fuel-Efficient Cars," accessed March 10, 2020, https://www.npr.org/ 2019/07/25/745389326/california-signs-deal-with-automakers-to-producefuel-efficientcars?t=1569794744209.

Wendt, Alexander. 1992. "Anarchy is What States Make of It: the Social Construction of Power Politics." International Organization 46(2): 391-425.

White House. 2014. "US-China Joint Announcement on Climate Change and Clean Energy Cooperation." Fact sheet. Accessed https://obamawhitehouse. archives.gov/the-press-office/2014/11/11/us-china-joint-announcement-cli mate-change

World Bank. 2013. China 2030: Building a Modern, Harmonious, and Creative Society. Washington DC: World Bank

Xi, Jinping. 2014. "Seek Sustained Development and Fulfil the Asia-Pacific Dream." Accessed March 10, 2020, https://www.fmprc.gov.cn/mfa_eng/ topics_665678/ytjhzzdrsrcldrfzshyjxghd/t1210456.shtml

Xi, Jinping. 2015. "Work together to Build a Win-win, Equitable and Balanced 
Governance Mechanism on Climate Change." Accessed March 10, 2020, https://unfccc.int/sites/default/files/cop21cmp11_leaders_event_china.pdf 